\title{
NUTRIENT LEACHING POTENTIAL FOLLOWING APPLICATION OF PAPERMILL LIME-SLUDGE TO AN ACIDIC CLAY SOIL ${ }^{(1)}$
}

\author{
S. C. VETTORAZZO(2), F. C. S. AMARAL ${ }^{(3)} \&$ J . C. CHITOLINA ${ }^{(4)}$
}

\begin{abstract}
SUMMARY
This experiment was carried out under greenhouse conditions with soil pots during $\mathbf{2 1 0}$ days, to evaluate the effect of calcitic papermill lime-sludge application (at the rates $0,773,1.547$, and $2.320 \mathrm{mg} \mathrm{kg}^{-1}$ or respective equivalents to control, 2, 4, and $6 \mathrm{t} \mathrm{ha}^{-1}$ ), on chemical composition of soil leachate and its effects on eucalypt growth and yield. Highest soil leachate $\mathbf{p H}, \mathrm{SO}_{4}$, and $\mathrm{Na}$ concentrations occurred in the 4 and $6 \mathrm{t} \mathrm{ha}^{-1}$ treatments. Soil leachate nitrate concentrations decreased with increasing lime-sludge rate. Soil leachate phosphate remained low (below the detection limit) in all treatments until 120 days, while the concentration increased in the lime-sludge treatments at 210 days (last sampling) in about $600 \mathrm{mg} \mathrm{L}^{-1}$. Lime-sludge decreased leachate $\mathbf{M g}$ concentration, but had no significant effect among rates. Soil leachate $\mathrm{Ca}, \mathrm{K}, \mathrm{B}$, $\mathrm{Cu}, \mathrm{Fe}$, and $\mathrm{Zn}$ did not change si gnificantly for any lime-sludge application rates. The maximum $\mathrm{NO}_{3}, \mathrm{Ca}, \mathrm{Mg}, \mathrm{K}$, and Na concentrations in the soil leachate occurred at 60 days after lime-sludge application (leaching equivalent to 1 pore volume), but for $\mathrm{pH}$ and $\mathrm{SO}_{4}$, the maximum occurred at 210 days (leaching equivalent to 4 pore volumes). Lime-sludge application decreased the concentration of exchangeable Al in the soil. Plant diameter growth and dry matter yield were increased with increasing lime-sludge rate. Beneficial effects on mi neral nutrition ( $P, K, C a, B$, and $\mathrm{Zn}$ ) of eucalypts were also obtained by the application of 4 and $6 \mathrm{t} \mathrm{ha} \mathbf{a}^{-1}$ of lime-sludge.

Index terms: eucalypt, industrial residue, soil fertility, mineral nutrition, sodium, recycling.

\footnotetext{
(1) Research with financial support of the Brazilian Council of Research - CNPq / Programa Rhae and Champion Papel e Celulose, presently International Paper . Received for publication in September 2000 and aproved in April 2001.

(2) Biologist, Praça Santos Dumont 22/302, CEP 22470-060 Rio de J aneiro (RJ ).

(3) Researcher, Embrapa Solos, Rua J ardim Botânico 1024, CEP 22460-000 Rio de J aneiro (RJ ). E-mail: fernando@cnps.embrapa.br

(4) Professor, Departamento de Ciências Exatas, Escola Superior de Agricultura "Luiz de Queiroz" - ESALQ/USP, and Curso de Farmácia e Bioquímica, UNOESTE. Caixa Postal 09, CEP 13418-900 Piracicaba (SP).
} 

RE SUMO: POTENCIAL DE LIXIVIAÇÃO DE NUTRIENTES EM UM SOLO ARGILOSO ÁCIDO APÓS A APLICAÇÃO DE LAMA DE CAL PROVENIENTE DE INDÚSTRIA DE PAPEL

\begin{abstract}
E m casa de vegetação, realizou-se um experimento em vasos durante 210 dias, para aval iar os efeitos da aplicação no sol o de um resíduo cal cítico proveniente da indústria de pape, a lama decal , nas doses 0, 773, 1.547 e $2.320 \mathrm{mg} \mathrm{kg}^{-1}$, equivalentes ao control e, 2, 4 e 6 t ha-1, respectivamente, sobre a composição química do lixiviado do sol o e seus efeitos no crescimento e na produção de mudas de eucalipto. Os maiores valores de pH e das concentrações de $\mathrm{SO}_{4}$ e Na no lixiviado do sol o ocorreram nos tratamentos com 4 e 6 t ha-1. As concentrações de $\mathrm{NO}_{3}$ no lixiviado do sol o di minuíram com o aumento da dose de lama decal aplicada. As concentrações dePO ${ }_{4}$ no lixi viado do sol o permaneceram baixas (abaixo do li mi te mínimo de detecção) em tod os os tratamentos até 120 dias, enquanto, aos 210 dias (última amostragem), essas concentrações aumentaram nos tratamentos com lama de cal, sendo da ordem de $600 \mathrm{mg} \mathrm{L}^{-1}$. A concentração deMg no lixiviado diminuiu com a aplicação delama decal, mas não houve efe to significativo entreas doses. As concentrações deCa, $\mathrm{K}$, $\mathrm{B}, \mathrm{Cu}, \mathrm{FeeZn}$ nolixiviado não foram signi ficati vamenteinfluenciadas pel as doses delama de cal aplicadas no sol o. As concentrações máximas de $\mathrm{NO}_{3}, \mathrm{Ca}, \mathrm{Mg}, \mathrm{K}$ eNa no lixi viado do solo ocorreram após 60 dias da aplicação da lama decal (lixi viação equivalentea uma vez o volume total de poros), mas, para $\mathrm{pH} \mathrm{eSO}_{4}$, os valores máximos ocorreram aos 210 dias da apli cação (lixi viação equival entea quatro vezes o volume total de poros). A aplicação de I ama decal diminuiu a concentração deAl trocável no sol o. O cresci mento em diâmetro das plantas ea produção de matéria seca aumentaram com o aumento da dose de lama de cal. Efeitos benéfi cos na nutrição mineral $(P, K, C a, B$ e Zn) do eucal ipto foram obti dos com a aplicação de 4 e 6 t ha-1delama de cal.
\end{abstract}

Termos de indexação: eucalipto, resíduo industrial, fertilidade do solo, nutrição mineral, sódio, reciclagem.

\section{INTRODUCTION}

Numerous studies conducted during the past three decades have demonstrated the potential benefits to forest and agricultural soils from the application of by-products, such as wood ash, lime by-products, sludge and other organic materials which are produced by the pulp and paper industry. These benefits include increased plant growth and yield, increased soil fertility, and improved soil moisture retention (Dolar et al., 1972; Simson et al., 1981; Naylor \& Schmidt, 1986; Bockheim et al., 1988; Stape \& Balloni, 1988; Bellamy et al., 1995). Adverse effects from land application of papermill byproducts have been associated with high soluble salt levels, especially sodium ( $\mathrm{Na}$ ), and concern for groundwater contamination caused by potential leaching of nitrates and heavy metals (Harkin, 1982; Bockheim et al., 1988; Bellamy et al., 1995; Williams et al., 1996).

Various manufacturing lime by-products can be used to neutralize soil acidity. One of these, limesludge, results from a process designed to recover high cost chemicals from the digestion liquor used in the kraft paper process (Simson et al., 1981; Muse $\&$ Mitchell, 1995). Calcium oxide reacts with spent (used) liquor, yielding mainly $\mathrm{CaCO}_{3}, \mathrm{NaOH}$, and $\mathrm{Na}_{2} \mathrm{~S}$. These materials are filtered and washed to recover $\mathrm{NaOH}$ and $\mathrm{Na}_{2} \mathrm{~S}$. The $\mathrm{CaCO}_{3}$ can be converted back to $\mathrm{CaO}$ in a lime-kiln. This step requires large amounts of fuel or gas, and has a high investment, since some pulpmill recovery systems accumulate a portion of lime-sludge due to the low capacity of the kiln burning lime-sludge to recover lime. Little information is available on the use of lime-sludge and the other lime by-products (dregs, grits) in Brazilian soils. At present, most of these lime by-products are under utilized as soil liming agents, but many of these could benefit forest production, by supplying essential plant nutrients low in forest soils.

The development of this study was motivated by the increasing interest in land application of limesludge from a paper pulp mill to acid soils of southeastern Brazil. Our objective was to determine the effects of papermill lime-sludge application on chemical composition of soil leachate and their effects on eucalypt growth and yield.

\section{MATERIALS AND METHODS}

\section{Soil and lime-sludge}

Soil samples were collected in a commercial eucalypt area in Mogi-Guaçu (SP), in J anuary 1998, at two depths, $0-20 \mathrm{~cm}$ and $20-40 \mathrm{~cm}$. The soil samples used for this study were identified and 
classified previously as "Latossolo VermelhoAmarelo distrófico" (LVAd). The papermill limesludge sample used was obtained from the Champion Co. located at Mogi-Guaçu (SP).

\section{Greenhouse study}

Sixteen polyethyleneplastic pots ( $30 \mathrm{~cm}$ in height by $24 \mathrm{~cm}$ in diameter), were filled with $15 \mathrm{~kg}$ of soil [7.5 kg of the subsurface layer $(20-40 \mathrm{~cm})$ placed at the bottom of the pot overlain by $7.5 \mathrm{~kg}$ of the surface layer $(0-20 \mathrm{~cm})]$. The experimental design consisted of four lime-sludge rates $(0,773,1.547$, and $2.320 \mathrm{mg} \mathrm{kg}^{-1}$, or equivalent to control, 2, 4, and $6 \mathrm{t} \mathrm{ha}^{-1}$, respectively) and four soil leachate sampling times $(2,60,120$ and 210 days after lime-sludge application, or equivalent to $0.3,1.0,2.0$, and 4.0 pore volumes of drainage, respectively). There were four replicates per treatment. Lime-sludge was applied on the surface and mixed in the first $3 \mathrm{~cm}$ of soil. All pots were wetted with distilled water several times a week to maintain soil moisture near to $60-70 \%$ of field capacity, except at leachate sampling time, when the soil was water-saturated to allow the collection of $250 \mathrm{ml}$ of leachate solution. Leachate samples were placed in plastic bottles, and stored at $4^{\circ} \mathrm{C}$. Leachateanalysis were completed within 1 week after collection.

After the first 60 days, one young hybrid plant of Eucalyptus grandis $x \mathrm{E}$. urophylla (about 90 days old) was planted in the center of each pot. The plants were harvested about $1 \mathrm{~cm}$ above the soil surface after 150 days, and measured for diameter growth ( $2 \mathrm{~cm}$ above the surface of the soil). Plant samples were dried for $48 \mathrm{~h}$ at $65^{\circ} \mathrm{C}$ in a convection oven, weighed for dry matter yield, and ground in a Wiley mill to pass a $1 \mathrm{~mm}$ screen, in preparation for elemental analysis (Malavolta et al., 1989).

Soil samples were collected at the end of the experiment of each treatment (surface and subsurface layers) to indicate changes in soil chemical characteristics and to determine if any unexpected element resulted from lime-sludge application.

\section{Analysis of soil, lime-sludge and plants}

Particle-size distribution of the soil samples was determined by the pipette method (EMBRAPA, 1997). Soil chemical characteristics were determined by methods outlined in Raij et al. (1987): $\mathrm{pH}$ in $\mathrm{CaCl}_{2}$ $0.01 \mathrm{~mol} \mathrm{~L}^{-1}$; organic matter by the colorimetric method; available $\mathrm{P}$, and exchangeable $\mathrm{Ca}, \mathrm{Mg}$, and $\mathrm{K}$ were extracted by the cation-anion-exchangeresin method, following $\mathrm{P}$ determined by the col orimetric (molybdenum blue) method, $\mathrm{Ca}$ and $\mathrm{Mg}$ determined by atomic absorption spectrophotometry (AAS), and $\mathrm{K}$ by flame emission spectrometry (FES); exchangeableAl was extracted with a $1 \mathrm{~mol} \mathrm{~L}^{-1} \mathrm{KCl}$ extract and determined by titrimetric method; exchangeable $\mathrm{Na}$ was extracted with a $0.1 \mathrm{~mol} \mathrm{~L}^{-1}$ $\mathrm{KCl}$ extract and determined by FES; B was extracted with hot-water and determined by the colorimetric method of azomethine-H; $\mathrm{Cu}, \mathrm{Fe}, \mathrm{Mn}$, and $\mathrm{Z}$ were extracted by DTPA-TEA extracts and determined by $\mathrm{AAS}$, and $\mathrm{SO}_{4}-\mathrm{S}$ was extracted with a $0.5 \mathrm{~mol} \mathrm{~L}^{-1}$ $\mathrm{NH}_{4} \mathrm{OAc}$ extract in $0.25 \mathrm{~mol} \mathrm{~L}^{-1} \mathrm{HOAc}$ extract and determined by the turbidimetric method (Vitti, 1989).

The lime-sludge $\mathrm{pH}$ was measured in $\mathrm{CaCl}_{2}$ $0.01 \mathrm{~mol} \mathrm{~L}^{-1}$, and organic matter by loss on ignition (Kiehl, 1985). Lime-sludge and plant subsamples were digested with nitric and perchloric acid and the concentrations of $\mathrm{P}, \mathrm{K}, \mathrm{Ca}, \mathrm{Mg}, \mathrm{S}, \mathrm{Na}, \mathrm{B}, \mathrm{Cu}, \mathrm{Fe}$, $\mathrm{Mn}$, and $\mathrm{Zn}$ were determined as above. Total $\mathrm{N}$ was determined by the micro-Kjeldahl method (Kiehl, 1985; Malavolta et al., 1989).

The leachate subsamples used for immediate $\mathrm{pH}$ measurements were also used for $\mathrm{NO}_{3}$ and $\mathrm{PO}_{4}$ analysis, determined by the micro-Kjeldahl and col orimetric methods, respectively, within $48 \mathrm{~h}$ after collection. Subsequently, $\mathrm{Ca}, \mathrm{Mg}, \mathrm{K}, \mathrm{Na}, \mathrm{Cu}, \mathrm{Fe}, \mathrm{Zn}$, $\mathrm{SO}_{4}$ and $\mathrm{B}$ concentrations were determined as above for soil analysis.

Sodium adsorption ratio (SAR) of the soil leachate was calculated by the formula proposed by the United States Salinity Laboratory Staff (1969).

\section{Statistical analysis}

Data were submitted to analysis of variance and correlation analysis. The Tukey's test was used to compare mean values for each variable studied. Statistical Analysis System softwarewas used toanalyze the data (SAS INSTITUTE, 1990) and condusions were assessed at a significance level of $P<0.05$.

\section{RESULTS AND DISCUSSION}

\section{Soil and lime-sludge characterization}

Selected chemical characteristics, and particle-size distribution of soil are presented in table 1. It is an acidic day soil, with medium organic matter amount, low nutrient concentrations ( $\mathrm{P}, \mathrm{Ca}, \mathrm{Mg}$ and $\mathrm{K})$, and a high aluminum concentration (Raij et al., 1987).

Total concentrations of various major and trace elements in the papermill lime-sludge for several cations and anions are presented in table 2. Limesludge had alkaline pH (9.7); low total organic matter (44 $\mathrm{mg} \mathrm{kg}^{-1}$ ); high $\mathrm{Ca}, \mathrm{Na}$, S, Fe, and $\mathrm{Mn}$ concentrations (321, 39, 7, $2.6 \mathrm{~g} \mathrm{~kg}^{-1}$, and $415 \mathrm{mg} \mathrm{kg}^{-1}$, respectively); average $\mathrm{Zn}$ concentration $\left(62 \mathrm{mg} \mathrm{kg}^{-1}\right)$; low $\mathrm{Mg}$ concentration $\left(2.5 \mathrm{~g} \mathrm{~kg}^{-1}\right)$, and very low concentrations of other metals and other constituents $\left(1.22 \mathrm{~g} \mathrm{~kg}^{1} \mathrm{P}\right.$, $1.33 \mathrm{~g} \mathrm{~kg}^{-1} \mathrm{~K}$, and $3 \mathrm{mg} \mathrm{kg}^{-1} \mathrm{Cu}$ ); with the exception of $\mathrm{S}$ and $\mathrm{Cu}$, concentrations were within ranges previously reported (Simson et al., 1981; Stappe \& Balloni, 1988; Benedetti, 1994; Muse\& Mitchell, 1995). Individual lime-sludge particles are very fine 
Table 1. Chemical characteristics and particle-size distribution of the soil used in this study

\begin{tabular}{|c|c|c|c|c|c|c|c|c|c|c|c|}
\hline \multirow{2}{*}{ Soil depth } & \multirow{2}{*}{$\mathrm{pH}\left(\mathrm{CaCl}_{2}\right)$} & \multirow{2}{*}{ Organic matter } & \multirow{2}{*}{$P$ resin } & \multicolumn{5}{|c|}{ Exchangeable cations } & \multicolumn{3}{|c|}{$\begin{array}{l}\text { Particle-size } \\
\text { distribution }\end{array}$} \\
\hline & & & & Al & $\mathrm{Ca}$ & Mg & $\mathbf{K}$ & $\mathrm{Na}$ & Sand & Silt & Clay \\
\hline $\mathrm{cm}$ & & $\mathrm{g} \mathrm{dm} \mathrm{m}^{-3}$ & $\mathrm{mg} \mathrm{dm}{ }^{-3}$ & 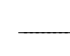 & -1 & nol $_{c} d n$ & B & - & $\longrightarrow$ & $\mathrm{kg}^{-1}$ & - \\
\hline $0-20$ & 3.7 & 47 & 4 & 17 & 2 & 1 & 0.6 & 0.2 & 479 & 89 & 432 \\
\hline $20-40$ & 3.8 & 32 & 2 & 13 & 1 & 1 & 0.6 & 0.1 & 474 & 99 & 427 \\
\hline
\end{tabular}

$(<0.3 \mathrm{~mm} \cong 97 \%)$, and this material is classified as industrial calcitic lime (Bergamin et al., 1994). The calcium carbonate equivalency of this lime-sludge was about $81 \%$. Taking into account theliming value of lime-sludge and the quantities produced by the pulp and paper industry (an average of 3,000 t per year was produced by each Brazilian mill), this material can be considered as under utilized as a soil liming amendment, due to the low number of land application programs in the southeast United States (Muse \& Mitchell, 1995) and Brazil.

\section{Leachate composition}

The $\mathrm{pH}$ values in the soil leachate increased significantly with increasing lime-sludge rate and days after application (Table 3 ). The leachate $\mathrm{pH}$ in the $2 \mathrm{t} \mathrm{ha}^{-1}$ treatment increased from 3.4 to 4.2 after 210 days of lime-sludge application; in the $4 \mathrm{t} \mathrm{ha-1}$ treatment increased from 3.5 to 4.8; and in the $6 \mathrm{t} \mathrm{ha}^{-1}$ treatment increased from 3.5 to 5.2 . Leachate $\mathrm{pH}$ values were positively correlated with leachate $\mathrm{PO}_{4}$ concentration $(r=0.709, \mathrm{P}<0.01)$, leachate $\mathrm{SO}_{4}$ concentration ( $r=0.915, \mathrm{P}<0.01)$, and leachate $\mathrm{Na}$ concentration $(r=0.925, \mathrm{P}<0.01)$ and negatively correlated with leachate $\mathrm{NO}_{3}$ concentration $(r=-0.511$, $P<0.05)$ and leachate $M g$ concentration $(r=-0.591$, $\mathrm{P}<0.05)$. These increases in theleachate $\mathrm{pH}$ values were due to the presence of carbonates, oxides, hydroxides, and other alkaline compounds (40 g kg-1 of $\mathrm{Na}$, Table 2) in thelime-sludgechemical composition (Simson et al., 1981; Muse \& Mitchell, 1995). At the end of the experiment (210 days), differences in leachate $\mathrm{pH}$ values between control and lime-sludge treatments were still significant, but no difference was observed between $4 \mathrm{t} \mathrm{ha}^{-1}$ treatment and $6 \mathrm{t} \mathrm{ha}^{-1}$ treatment.

Nitrate is usually the major inorganic form of $\mathrm{N}$, as well as the dominant anion in the water percolated through most of the soil (White, 1997). Leachate $\mathrm{NO}_{3}$ concentration in the control ranged from 62 to $171 \mathrm{mg} \mathrm{L}^{-1}$, while in the lime-sludge treatments ranged from 39 to $199 \mathrm{mg} \mathrm{L}^{-1}$ (Table 3). Concentrations of $\mathrm{NO}_{3}$ in the soil leachate decreased with increasing lime-sludge rate (ranging from 125 to $88 \mathrm{mg} \mathrm{L}^{-1}$, respectively, for control and $6 \mathrm{t} \mathrm{ha}^{-1}$ ) and with days after application. The maximum $\mathrm{NO}_{3}$ concentrations in the soil leachate occurred during the first 60 days after lime-sludge application (leaching equivalent to 1 pore volume), prior to eucalypt planting, and did not differ among application rates. Lowest concentrations of $\mathrm{NO}_{3}$ occurred during the last sampling (leaching equivalent to 4 pore volumes), and except for the control, all lime-sludge treatments did not exceed drinking-water standards for human consumption of $45 \mathrm{mg} \mathrm{L}^{-1}$ of $\mathrm{NO}_{3}$ (i.e., $10 \mathrm{mg} \mathrm{L}^{-1}$ of $\mathrm{NO}_{3}$ expressed as $\mathrm{N}$ ), established by the United States Environmental Protection Agency (USEPA, 1977). Probably, plant uptake was sufficient to decrease the leachate $\mathrm{NO}_{3}$ concentration in thelime-sludgetreatments. Nitrate concentration gradually declined as the readily available organic $\mathrm{N}$ was consumed and $\mathrm{NO}_{3}$ was removed by leaching and by plant uptake of $\mathrm{NO}_{3}$, indirectly by plant uptake of $\mathrm{NH}_{4}$ at the expense of nitrification, or by a combination of both mechanisms (Novais et al., 1990; White, 1997). In contrast to phosphate and the cationic plant nutrients, which are mainly involved in physical-chemical processes, the mobility of $\mathrm{N}$ in the soil depends largely on biological processes (Mengel \& Kirkby, 1982).

According to Lindsay (1979), the predominant solution phosphate species at the $\mathrm{pH}$ range of 3.5 to 7.0 is $\mathrm{H}_{2} \mathrm{PO}_{4}^{-}$. Orthophosphate concentration in the soil leachate remained near detection limits (0.03 $\mathrm{mg} \mathrm{PO}_{4} \mathrm{~L}^{-1}$ ) during the first 120 days following lime-sludge application. The last sampling showed $\mathrm{PO}_{4}$ concentrations ranging from bel ow the detection limits in the control to about $600 \mathrm{mg} \mathrm{L}^{-1}$ in thelimesludgetreatments. Soil pH, clay, sesqui oxide content and exchangeable aluminum all influence $P$ availability. In comparison with adsorbed $\mathrm{PO}_{4}$, the amount of $\mathrm{PO}_{4}$ present in soil solution at any given time is very low, due to the low solubility of $P$ compounds in the soil, and to the high $\mathrm{P}$-adsorption capacity of soil particles, a process called phosphate 'fixation' (Raij, 1991). In this study, the increase of phosphate in the last leachate can be attributed to leachate $\mathrm{pH}$ rise rather than tolime-sludge additions by treatments. However, the phosphate in the solution is actively absorbed by plants and readily reacts with $\mathrm{Al}, \mathrm{Fe}$, and $\mathrm{Mn}$ in acidic soils, which minimizes the potential for $\mathrm{P}$ mobility. 
Table 2. Chemical characteristics, $\mathrm{C} / \mathrm{N}$ ratio, and application rate of the lime-sludge

\begin{tabular}{|c|c|c|c|c|c|c|c|c|c|c|c|c|c|}
\hline \multirow{2}{*}{ Lime-sludge } & \multicolumn{11}{|c|}{ Concentration or application rate } & \multirow{2}{*}{$\begin{array}{c}\mathbf{p H} \\
\left(\mathrm{CaCl}_{2}\right)\end{array}$} & \multirow{2}{*}{$\begin{array}{c}\mathrm{C} / \mathrm{N} \\
\text { ratio }\end{array}$} \\
\hline & $\mathbf{N}$ & $\mathbf{P}$ & $\mathbf{s}$ & $\mathrm{Ca}$ & Mg & $\mathbf{K}$ & $\mathbf{N a}$ & $\mathbf{F e}$ & $\mathbf{C u}$ & Mn & $Z n$ & & \\
\hline \multirow{3}{*}{ Conc. } & & & & $-g$ & $y^{-1}$ & & & & $\ldots$ & $\mathrm{ng} \mathrm{kg}$ & - & & \\
\hline & 0.70 & 1.22 & 7.10 & 320.9 & 2.50 & 1.33 & 38.9 & 2.62 & 3.00 & 415 & 62.0 & 9.7 & 36 \\
\hline & \multicolumn{8}{|c|}{$\mathrm{kg} \mathrm{ha}^{-1}$} & & $\mathrm{~g} \mathrm{ha}^{-1}$ & & & \\
\hline t ha-1 & 0.67 & 1.17 & 6.78 & 306.5 & 2.38 & 1.27 & 37.2 & 2.49 & 2.87 & 396 & 59.2 & & \\
\hline
\end{tabular}

Table 3. Effect of lime-sludge rates and sampling times on soil leachate composition

\begin{tabular}{|c|c|c|c|c|}
\hline \multirow{2}{*}{ Lime-sludge } & \multicolumn{4}{|c|}{ Sampling time } \\
\hline & 2 days & 60 days & 120 days & 210 days \\
\hline rate & \multicolumn{4}{|c|}{$\mathrm{pH}$} \\
\hline $\begin{array}{l}\text { Control } \\
2 \mathrm{t} \mathrm{ha}^{-1} \\
4 \mathrm{t} \mathrm{ha}^{-1} \\
6 \mathrm{tha}^{-1}\end{array}$ & $\begin{array}{l}3.30 \mathrm{bB} \\
3.43 \mathrm{abC} \\
3.50 \mathrm{aC} \\
3.50 \mathrm{aD}\end{array}$ & $\begin{array}{l}3.15 \mathrm{cB} \\
3.43 \mathrm{bcC} \\
3.68 \mathrm{abC} \\
3.95 \mathrm{aC}\end{array}$ & $\begin{array}{l}3.70 \mathrm{cA} \\
3.93 \mathrm{cB} \\
4.23 \mathrm{bB} \\
4.68 \mathrm{aB}\end{array}$ & $\begin{array}{l}3.75 \mathrm{bA} \\
4.15 \mathrm{bA} \\
4.75 \mathrm{aA} \\
5.15 \mathrm{aA}\end{array}$ \\
\hline $\begin{array}{l}\text { Control } \\
2 \mathrm{t} \mathrm{ha}^{-1} \\
4 \mathrm{t} \mathrm{ha}^{-1} \\
6 \mathrm{tha}^{-1}\end{array}$ & $\begin{array}{l}31.5 \mathrm{abA} \\
33.3 \mathrm{aA} \\
28.0 \mathrm{abA} \\
21.0 \mathrm{bB}\end{array}$ & $\begin{array}{l}34.1 \mathrm{aA} \\
35.0 \mathrm{aA} \\
32.8 \mathrm{aA} \\
31.9 \mathrm{aA}\end{array}$ & $\begin{array}{l}27.1 \mathrm{abA} \\
14.0 \mathrm{cB} \\
34.1 \mathrm{aA} \\
16.6 \mathrm{bcBC}\end{array}$ & $\begin{array}{r}20.1 \mathrm{aA} \\
9.7 \mathrm{aB} \\
8.8 \mathrm{aB} \\
10.1 \mathrm{aC}\end{array}$ \\
\hline $\begin{array}{l}\text { Control } \\
2 \mathrm{t} \mathrm{ha}^{-1} \\
4 \mathrm{t} \mathrm{ha}^{-1} \\
6 \mathrm{tha}^{-1}\end{array}$ & $\begin{array}{l}0.38 \mathrm{aA} \\
0.26 \mathrm{aB} \\
1.88 \mathrm{aB} \\
1.50 \mathrm{aB}\end{array}$ & $\begin{array}{l}0.13 \mathrm{aA} \\
0.03 \mathrm{aB} \\
1.38 \mathrm{aB} \\
2.75 \mathrm{aB}\end{array}$ & $\begin{array}{l}0.75 \mathrm{bA} \\
1.13 \mathrm{bAB} \\
6.75 \mathrm{abB} \\
7.03 \mathrm{aB}\end{array}$ & $\begin{array}{r}0.26 \mathrm{bA} \\
2.05 \mathrm{bA} \\
17.13 \mathrm{bA} \\
27.63 \mathrm{aA}\end{array}$ \\
\hline $\begin{array}{l}\text { Control } \\
2 \mathrm{t} \mathrm{ha}^{-1} \\
4 \mathrm{t} \mathrm{ha}^{-1} \\
6 \mathrm{tha}^{-1}\end{array}$ & $\begin{array}{l}4.0 \\
3.8 \\
2.5 \\
2.8\end{array}$ & $\begin{array}{l}6.8 \\
3.3 \\
3.5 \\
3.5\end{array}$ & $\begin{array}{l}1.2 \\
0.8 \\
1.0 \\
1.0\end{array}$ & $\begin{array}{l}1.8 \\
0.8 \\
1.0 \\
0.8\end{array}$ \\
\hline $\begin{array}{l}\text { Control } \\
2 \mathrm{tha}^{-1} \\
4 \mathrm{t} \mathrm{ha}^{-1} \\
6 \mathrm{tha}^{-1}\end{array}$ & $\begin{array}{l}1.48 \\
1.48 \\
0.98 \\
0.98\end{array}$ & $\begin{array}{l}2.25 \\
1.60 \\
1.30 \\
0.95\end{array}$ & $\begin{array}{l}1.20 \\
0.28 \\
0.20 \\
0.10\end{array}$ & $\begin{array}{l}1.08 \\
0.30 \\
0.30 \\
0.20\end{array}$ \\
\hline $\begin{array}{l}\text { Control } \\
2 \mathrm{tha}^{-1} \\
4 \mathrm{t} \mathrm{ha} \mathrm{a}^{-1} \\
6 \mathrm{tha}^{-1}\end{array}$ & $\begin{array}{l}1.68 \\
2.15 \\
2.15 \\
1.85\end{array}$ & $\begin{array}{l}2.83 \\
2.68 \\
3.30 \\
2.35\end{array}$ & $\begin{array}{l}0.50 \\
0.50 \\
0.50 \\
0.50\end{array}$ & $\begin{array}{l}0.01 \\
0.01 \\
0.01 \\
0.01\end{array}$ \\
\hline $\begin{array}{l}\text { Control } \\
2 \mathrm{t} \mathrm{ha}^{-1} \\
4 \mathrm{t} \mathrm{ha}^{-1} \\
6 \mathrm{t} \mathrm{ha}^{-1}\end{array}$ & $\begin{array}{c}2.09 \mathrm{bA} \\
14.94 \mathrm{abA} \\
24.44 \mathrm{aAB} \\
21.75 \mathrm{aB}\end{array}$ & $\begin{array}{r}1.44 \mathrm{bB} \\
14.88 \mathrm{bA} \\
35.75 \mathrm{aA} \\
37.75 \mathrm{aA}\end{array}$ & $\begin{array}{c}0.11 \mathrm{bC} \\
4.36 \mathrm{bB} \\
27.88 \mathrm{aAB} \\
33.13 \mathrm{aA}\end{array}$ & $\begin{array}{c}0.30 \mathrm{bC} \\
2.45 \mathrm{bB} \\
16.75 \mathrm{aB} \\
25.25 \mathrm{aAB}\end{array}$ \\
\hline $\begin{array}{l}\text { Control } \\
2 \mathrm{tha}^{-1} \\
4 \mathrm{t} \mathrm{ha}^{-1} \\
6 \mathrm{t} \mathrm{ha}^{-1}\end{array}$ & $\begin{array}{l}0.32 \mathrm{bA} \\
2.40 \mathrm{abA} \\
4.69 \mathrm{aB} \\
4.00 \mathrm{abB}\end{array}$ & $\begin{array}{l}0.17 \mathrm{bB} \\
2.45 \mathrm{bA} \\
6.78 \mathrm{aAB} \\
6.88 \mathrm{aB}\end{array}$ & $\begin{array}{c}0.03 \mathrm{bC} \\
1.43 \mathrm{bAB} \\
9.43 \mathrm{aA} \\
11.95 \mathrm{aA}\end{array}$ & $\begin{array}{c}0.07 \mathrm{bC} \\
0.87 \mathrm{bB} \\
5.31 \mathrm{abB} \\
12.38 \mathrm{aA}\end{array}$ \\
\hline
\end{tabular}

Different small letters within rows and capital letters within a columns, indicate means that are significantly different by Tukey test at the $5 \%$ probability level. Absence of letter in rows or columns indicates there was no significant difference by $\mathrm{F}$ test. 
Leachate $\mathrm{SO}_{4}$ concentrations remained low for the first 60 days after lime-sludge application, ranging from below the detection limits $\left(0.03 \mathrm{mg} \mathrm{L}^{-1}\right)$ to $16.5 \mathrm{mg} \mathrm{L}^{-1}$, and there wereno significant differences in concentrations among any of the treatments (Table 3). After this time, $\mathrm{SO}_{4}$ concentrations in the lime-sludge treatments began to increase and continued to increase to maximum concentrations at 210 days, while concentrations in the control remained relatively constant. According to Parfitt (1978), losses of sulfate by leaching are more significant in soils that are low in hydrous oxides of iron and aluminum, particularly in A horizons. Sulfate is adsorbed by soils less strongly than phosphate. The order of adsorption for different anions is phosphate $>$ molybdate $>$ sulfate $>$ chloride > nitrate.

Calcium, $\mathrm{Mg}$, and $\mathrm{K}$ in the soil leachate behaved similarly (Table 3). Highest concentrations of $\mathrm{Ca}, \mathrm{Mg}$, and $\mathrm{K}$ occurred during the first 60 days after limesludge application (leaching equivalent to 1 pore volume), before eucalypt planting. Calcium and $\mathrm{K}$ concentrations did not change significantly for any lime-sludge application rate (Ca varied from bel ow the detection limits to $8.0 \mathrm{mg} \mathrm{L}^{-1}$; and $\mathrm{K}$ from bel ow the detection limits to $5.1 \mathrm{mg} \mathrm{L}^{-1}$ ), while $\mathrm{Mg}$ was reduced significantly in thelime-sludge treatments in comparison with control ( $\mathrm{Mg}$ varied from 0.10 to $2.80 \mathrm{mg} \mathrm{L}^{-1}$ ). Calcium, $\mathrm{Mg}$, and $\mathrm{K}$ areheld mainly as exchangeable cations, the supply of which buffers the soil solution against depletion (White, 1997). Potassium leaching rates are relatively high in kaolinitic soils, because this clay mineral does not adsorb K selectively. Magnesium is only weakly adsorbed by kaolinitic clay mineral and, for this reason, it is particularly susceptible to leaching. Calcium is also not strongly adsorbed by inorganic colloids, and it is often the dominant cation in the water percolated through most of the soil (Tisdale et al., 1985). Low levels of Ca in the soil leachate can be associated with the low solubility of calcium carbonates present in the lime-sludge, by the soil retention of this cation, and by eucalypt removal.

Sodium concentrations in the soil leachate increased significantly with increasing lime-sludge application rates (Table 3). Changes in the concentrations of $\mathrm{Na}$ were similar in the control and in the $2 \mathrm{t} \mathrm{ha}^{-1}$ treatment, while other patterns wereevident in the treatments with 4 and $6 \mathrm{t} \mathrm{ha}^{-1}$. Lowest concentrations of $\mathrm{Na}$ occurred at 210 days, except for the $6 \mathrm{t} \mathrm{ha}^{-1}$ treatment. This suggests that most soluble $\mathrm{Na}$ had been removed with leaching equival ent to 4 pore vol umes. Sodium is only weakly adsorbed by clay minerals and, for this reason, it is particularly susceptibletoleaching. In well-drained soils, if higher concentrations of $\mathrm{Na}$ occur, this cation is leached more rapidly, while if lower concentrations occur, its rate of leaching is diminished (Lindsay, 1979).

The calculated SAR for the $2 \mathrm{t} \mathrm{ha}^{-1}$ lime-sludge treatment was below the limit of 5.0 (UNITED
STATES SALI NITY LABORATORY STAFF, 1969) during the experiment, indicating that sufficient exchangeable $\mathrm{Ca}$ and $\mathrm{Mg}$ were present to offset negative effects due to exchangeable $\mathrm{Na}$. On the other hand, the SAR of the leachate increases from below the limit to 5.0 at 2 days to 9.4 and 12.4 , respectively, to $4 \mathrm{t} \mathrm{ha}^{-1}$ treatment at 120 days and $6 \mathrm{t} \mathrm{ha}^{-1}$ at 210 days, indicating that adverse changes in the soil structure can occur. However, increases of $\mathrm{Na}$ amounts had no effect on soil permeability (visual observation of soil drainage) and root growth.

Boron concentrations were not affected by limesludge application, but decreased significantly during the experimental time. Concentrations of $\mathrm{Cu}$, $\mathrm{Fe}, \mathrm{Mn}$, and $\mathrm{Zn}$ in the soil leachate were very low or not detectable $\left(\leq 0.001 \mathrm{mg} \mathrm{L}^{-1}\right)$ in all thetreatments. The absence of micronutrients in the soil leachates was not particularly surprising. According to Sposito et al . (1982), the concentration of free mi cronutrients in the soil solution is normally very low, many times bel ow the detection limits. Because of precipitation and strong retention by mineral and organic surfaces, micronutrient losses by leaching are very low, except for B, and Feand $\mathrm{Mn}$ in some gleyed soils (White, 1997).

Nitrate was the major anion in the soil leachate of all treatments during the first 120 days, but in the last sampling in the lime-sl udge treatments, $\mathrm{PO}_{4}$ had become the dominant anion. Generally in acid soils, phosphate in the soil solution is a negligible component of the anion sum, because it forms insoluble precipitates with Feand AI. Furthermore, phosphate is required by plants in high amounts, which reduces markedly the potential for $P$ leaching. In the control, Ca was the dominant cation in the soil leachate, while in the lime-sludge treatments, $\mathrm{Na}$ was the dominant cation.

\section{Changes in the soil chemical characteristics}

Because thelime-sludge was surface-applied with incorporation only at the first $3 \mathrm{~cm}$ of soil, rate did not significantly affect soil $\mathrm{pH}\left(\mathrm{CaCl}_{2}\right)$ at depths of 5-15 and 15-30 cm (Table 4). On the other hand, the leachate $\mathrm{pH}$ values in the lime-sludge treatments were still increasing, notably in the 4 and $6 \mathrm{t} \mathrm{ha}^{-1}$ treatments, at the end of the experiment (Table 3). This demonstrates the role of soil buffering capacity in controlling leachate $\mathrm{pH}$ and soil $\mathrm{pH}$.

Exchangeable Al concetration in the soil was significantly reduced by the application of $6 \mathrm{t} \mathrm{ha}^{-1}$ (Table 4), resulting in precipitation of $\mathrm{Al}$ into relatively unavailable compounds. According to White (1997), most buffering in the $\mathrm{pH}\left(\mathrm{H}_{2} \mathrm{O}\right) 4$ to 5.5 range is due to exchangeable $\mathrm{Al}^{3+}$, and limesludge additions react readily with Al. The $\mathrm{pH}$ $\left(\mathrm{CaCl}_{2}\right)$ value is generally 0.6 to 0.8 units lower than $\mathrm{pH}\left(\mathrm{H}_{2} \mathrm{O}\right)$ at the same soil/liquid ratio.

Lime-sludge increased the concentration of $\mathrm{SO}_{4}-\mathrm{S}$ in the soil from the $5-15 \mathrm{~cm}$ depth from $17.3 \mathrm{mg} \mathrm{dm}^{-3}$ 
Table 4. Effect of lime-sludge rates on the soil chemical characteristics at two depths

\begin{tabular}{|c|c|c|c|c|}
\hline \multirow{2}{*}{ Soil chemical characteristic } & \multicolumn{4}{|c|}{ Lime-sludge rate } \\
\hline & Control & $2 \mathrm{t} \mathrm{ha}^{-1}$ & 4 t ha-1 $^{-1}$ & $6 \mathrm{t} \mathrm{ha}^{-1}$ \\
\hline & \multicolumn{4}{|c|}{ Surface layer, 5-15 cm } \\
\hline $\mathrm{pH}\left(\mathrm{CaCl}_{2}\right)$ & 3.70 & 3.75 & 3.80 & 4.05 \\
\hline Organic matter $\left(\mathrm{g} \mathrm{dm}^{-3}\right)$ & 39.5 & 34.3 & 33.0 & 34.5 \\
\hline$P$ resin $\left(\mathrm{mg} \mathrm{dm}^{-3}\right)$ & 4.0 & 4.0 & 3.3 & 3.8 \\
\hline $\mathrm{SO}_{4}-\mathrm{S}\left(\mathrm{mg} \mathrm{dm}^{-3}\right)$ & $17.3 \mathrm{c}$ & $23.3 \mathrm{~b}$ & $28.3 \mathrm{a}$ & $30.5 a$ \\
\hline Al $\left(\mathrm{mmol}_{\mathrm{c}} \mathrm{dm}^{-3}\right)$ & $18.5 \mathrm{a}$ & $17.5 \mathrm{a}$ & $16.8 \mathrm{a}$ & $12.5 \mathrm{~b}$ \\
\hline $\mathrm{Ca}\left(\mathrm{mmol}_{\mathrm{c}} \mathrm{dm}^{-3}\right)$ & 1.25 & 1.00 & 3.75 & 10.25 \\
\hline $\mathrm{K}\left(\mathrm{mmol}_{\mathrm{c}} \mathrm{dm}^{-3}\right)$ & 0.25 & 0.20 & 0.25 & 0.40 \\
\hline $\mathrm{Na}\left(\mathrm{mmol}_{\mathrm{c}} \mathrm{dm}^{-3}\right)$ & $0.23 \mathrm{~b}$ & $0.52 \mathrm{~b}$ & $1.04 \mathrm{a}$ & $1.51 \mathrm{a}$ \\
\hline$B\left(\mathrm{mg} \mathrm{dm}^{-3}\right)$ & 0.31 & 0.31 & 0.32 & 0.27 \\
\hline $\mathrm{Cu}\left(\mathrm{mg} \mathrm{dm}^{-3}\right)$ & 0.90 & 0.75 & 0.78 & 0.90 \\
\hline $\mathrm{Fe}\left(\mathrm{mg} \mathrm{dm}^{-3}\right)$ & 296 & 292 & 254 & 232 \\
\hline $\mathrm{Mn}\left(\mathrm{mg} \mathrm{dm}^{-3}\right)$ & 1.45 & 0.93 & 0.98 & 1.10 \\
\hline \multirow[t]{2}{*}{$\mathrm{Zn}\left(\mathrm{mg} \mathrm{dm}^{-3}\right)$} & 0.83 & 0.83 & 0.60 & 0.73 \\
\hline & \multicolumn{4}{|c|}{ Subsurface layer, $15-30 \mathrm{~cm}$} \\
\hline $\mathrm{pH}\left(\mathrm{CaCl}_{2}\right)$ & 3.80 & 3.85 & 3.83 & 3.83 \\
\hline Organic matter $\left(\mathrm{g} \mathrm{dm}^{-3}\right)$ & 27.0 & 27.0 & 25.5 & 26.8 \\
\hline$P$ resin $\left(\mathrm{mg} \mathrm{dm}^{-3}\right)$ & $3.3 \mathrm{a}$ & $2.8 \mathrm{a}$ & $3.0 \mathrm{a}$ & $2.0 \mathrm{~b}$ \\
\hline $\mathrm{SO}_{4}-\mathrm{S}\left(\mathrm{mg} \mathrm{dm}^{-3}\right)$ & $25.0 \mathrm{~b}$ & $30.5 \mathrm{~b}$ & $30.8 \mathrm{~b}$ & $41.3 \mathrm{a}$ \\
\hline Al $\left(\mathrm{mmol}_{\mathrm{c}} \mathrm{dm}^{-3}\right)$ & $16.3 \mathrm{a}$ & $16.5 \mathrm{a}$ & $15.5 a b$ & $14.0 \mathrm{~b}$ \\
\hline $\mathrm{Ca}\left(\mathrm{mmol}_{\mathrm{c}} \mathrm{dm}^{-3}\right)$ & 1.00 & 1.00 & 1.75 & 1.50 \\
\hline $\mathrm{K}\left(\mathrm{mmol}_{\mathrm{c}} \mathrm{dm}^{-3}\right)$ & 0.30 & 0.15 & 0.20 & 0.20 \\
\hline $\mathrm{Na}\left(\mathrm{mmol}_{\mathrm{c}} \mathrm{dm}^{-3}\right)$ & $0.21 \mathrm{c}$ & $0.45 c$ & $1.32 \mathrm{~b}$ & $1.80 \mathrm{a}$ \\
\hline$B\left(\mathrm{mg} \mathrm{dm}^{-3}\right)$ & 0.26 & 0.26 & 0.27 & 0.23 \\
\hline $\mathrm{Cu}\left(\mathrm{mg} \mathrm{dm}^{-3}\right)$ & 0.70 & 0.60 & 0.70 & 0.70 \\
\hline $\mathrm{Fe}\left(\mathrm{mg} \mathrm{dm}^{-3}\right)$ & 137 & 109 & 116 & 89 \\
\hline $\mathrm{Mn}\left(\mathrm{mg} \mathrm{dm}^{-3}\right)$ & 0.80 & 0.68 & 1.10 & 0.75 \\
\hline $\mathrm{Zn}\left(\mathrm{mg} \mathrm{dm}^{-3}\right)$ & 0.50 & 0.40 & 0.43 & 0.55 \\
\hline
\end{tabular}

Different letters within rows indicate means that are significantly different by the Tukey test at $5 \%$. Absence of letter in rows indicates no significant difference by the $\mathrm{F}$ test.

in the control to $30.5 \mathrm{mg} \mathrm{dm}^{-3}$ at $6 \mathrm{t} \mathrm{ha}^{-1}$, and from the $15-30 \mathrm{~cm}$ depth from $25 \mathrm{mg} \mathrm{dm}^{-3}$ in the control to $41.3 \mathrm{mg} \mathrm{dm}^{-3}$ at $6 \mathrm{t} \mathrm{ha}^{-1}$ (Table 4 ), due to the possible presence of $\mathrm{Na}_{2} \mathrm{~S}$ in this by-product (Simson et al., 1981).

Available phosphorus, exchangeable $\mathrm{Ca}, \mathrm{Mg}$, and $\mathrm{K}$, and trace metals did not change significantly for any lime-sludge application rate (Table 4). The variabilities of the $\mathrm{Ca}$ and $\mathrm{K}$ concentrations in the lime-sludge treatments were high and no consistent trends were apparent, except for Ca in the $5-15 \mathrm{~cm}$ depth which was increased eight-fold by the application of $6 \mathrm{t} \mathrm{ha}^{-1}$. This retention of $\mathrm{Ca}$ in the surface layer was due to an increase of cation exchange capacity arising out of an increase in $\mathrm{pH}$; negative charge on surfaces of variable charge minerals is increased by an increase in pH (Uehara \& Gillman, 1981).
Soil Na concentrations in the surface $(5-15 \mathrm{~cm})$ and in the subsurface layer $(15-30 \mathrm{~cm})$ were increased six-fold and eight-fold, respectively, by the application of $6 \mathrm{t} \mathrm{ha}^{-1}$ of lime-sludge at 210 days (Table 4). According to Tisdale et al. (1985), $\mathrm{Na}$ is not of immediate concern unless it occurs in excess of 10 to $20 \%$ of soil cation exchange capacity. High $\mathrm{Ca}$ in papermill lime by-products will replace $\mathrm{Na}$ on soil exchange sites, thus allowing $\mathrm{Na}$ to be leached from the soil and preventing $\mathrm{Na}$ accumulation in soils of humid regions.

Somestudies haveshown that application of limesludgeto forested sites tended to increase soil $\mathrm{pH}$ value and $\mathrm{Ca}$ concentration and decrease exchangeable $\mathrm{Al}$ concentration (Stape \& Balloni, 1988; Benedetti, 1994), but Na concentration has not been investigated. Utilization as a forest soil amendment would be a beneficial alternative to disposal. 


\section{Eucalypt response}

Plant diameter growth and dry matter yield increased significantly with increasing lime-sludge rate (Table 5). Plots amended with 2 or $6 \mathrm{t} \mathrm{ha}^{-1}$ of lime-sludge resulted in 43 to $65 \%$ more yield than control, respectively. These results are consistent with the data of Stape \& Balloni (1988), Benedetti (1994), and others presented by Guerrini \& VillasBôas (1996). Plant yield was positively correlated with leachate $\mathrm{pH}(r=0.758, \mathrm{P}<0.01)$, leachate $\mathrm{P}$ concentration $(r=0.876, \mathrm{P}<0.01)$, leachate $\mathrm{SO}_{4}$ concentration $(r=0.758, \mathrm{P}<0.01)$, and leachate $\mathrm{Na}$ concentration $(r=0.651, P<0.01)$.

Beneficial effects on eucalypt mineral nutrition were obtained with the application of lime-sludge (Table 5). It was observed that amounts of P, K, Ca, $\mathrm{Na}, \mathrm{B}$, and $\mathrm{Zn}$ in the eucalypt dry matter increased with increasing lime-sludge application rate. The amounts of $\mathrm{Cu}$ and $\mathrm{Mn}$ in the eucalypt plants decreased in all the lime-sludge treatments related to the control. Addition of lime-sludge did not change Mg uptake. However, induced Mg deficiency on field crops dueto the use of papermill lime-sludge should be a problem if soil exchangeable $\mathrm{Mg}$ is in an inadequate range (Simson et al., 1981; Guerrini \& Villas-B ôas, 1996).

Lime-sludge contained relatively high concentrations of $\mathrm{Na}$ (39 $\mathrm{mg} \mathrm{kg}^{-1}$, Table 2), but the eucalypt plants did not exhibit typical salt toxicity symptoms (stunted growth, necrosis of leaf tips) with thehigh lime-sludge rate $\left(6 \mathrm{t} \mathrm{ha}{ }^{-1}\right)$. There is evidence that exchangeable $\mathrm{Na}$ can partially substitute exchangeableK, when $\mathrm{K}$ in soil is low (Tisdale et al., 1985).

A subject of considerable concern when using papermill lime-sludge is the fate of potentially toxic $\mathrm{Na}$ and trace metal concentrations. Other concerns include the potential for metals leaching through the soil and polluting groundwater. However, our results indicate these concerns are unfounded. The fact that yields significantly increased with limesludge applications indicates that these papermill lime by-products can be effective at increasing soil solution $\mathrm{pH}$, reducing $\mathrm{Al}$ toxicity, and providing supplemental quantities of plant nutrients. The results of this study also suggest that lime-sludge which have $\mathrm{Na}$ concentration of about $40 \mathrm{mg} \mathrm{kg}^{-1}$ or less can possibly beapplied $\left(\leq 6 \mathrm{t} \mathrm{ha}^{-1}\right)$ to soils without immediate detrimental effects on eucalypt growth and yield. Because $\mathrm{Na}$ can become toxic to plant growth, a detailed evaluation of their availability in lime-sludge amended soils must be part of further studies of this type.

\section{CONCLUSIONS}

1. Soils amended with lime-sludge showed increases in soil leachate $\mathrm{pH}, \mathrm{PO}_{4}, \mathrm{SO}_{4}$, and $\mathrm{Na}$ concentrations and decreases in $\mathrm{NO}_{3}$ and $\mathrm{Mg}$ concentrations, 210 days after application. Calcium, $\mathrm{K}, \mathrm{B}, \mathrm{Cu}, \mathrm{Fe}$, and $\mathrm{Zn}$ leachate did not change significantly for any lime-sludge application rate.

Table 5. Effect of lime-sludge rate on eucalypt diameter growth, dry matter yield and nutrient uptake

\begin{tabular}{|c|c|c|c|c|}
\hline \multirow[b]{2}{*}{ Plant parameters } & \multicolumn{4}{|c|}{ Lime-sludge rate } \\
\hline & Control & 2 t ha-1 $^{-1}$ & $4 \mathrm{t} \mathrm{ha}^{-1}$ & $6 \mathrm{t} \mathrm{ha}^{-1}$ \\
\hline Diameter (mm) & $7.1 \mathrm{c}$ & $8.5 \mathrm{~b}$ & $9.2 \mathrm{ab}$ & $10.0 \mathrm{a}$ \\
\hline DM yield (g/pot) & $21.2 \mathrm{~b}$ & $30.3 a$ & $32.0 \mathrm{a}$ & $35.0 \mathrm{a}$ \\
\hline $\mathrm{N}$ (mg/pot) & $315 a b$ & $284 \mathrm{~b}$ & $356 a$ & $331 \mathrm{ab}$ \\
\hline $\mathrm{P}$ (mg/pot) & $19 \mathrm{c}$ & $24 \mathrm{~b}$ & 32 a & $34 a$ \\
\hline K (mg/pot) & $74 \mathrm{c}$ & $71 c$ & $116 \mathrm{~b}$ & $146 \mathrm{a}$ \\
\hline $\mathrm{Ca}$ (mg/pot) & $173 b$ & 481 a & 559 a & 557 a \\
\hline $\mathrm{Mg}$ (mg/pot) & 45 & 45 & 47 & 46 \\
\hline $\mathrm{S}$ (mg/pot) & $28 \mathrm{~b}$ & $28 \mathrm{~b}$ & 33 a & $31 a b$ \\
\hline $\mathrm{Na}(\mathrm{mg} / \mathrm{pot})$ & $9 \mathrm{c}$ & $82 \mathrm{~b}$ & $92 a b$ & $101 \mathrm{a}$ \\
\hline B $(\mu \mathrm{g} /$ pot $)$ & $724 \mathrm{~b}$ & $833 \mathrm{~b}$ & $1050 \mathrm{a}$ & $1097 a$ \\
\hline $\mathrm{Cu}(\mu \mathrm{g} / \mathrm{pot})$ & $168 a$ & $140 \mathrm{~b}$ & $76 d$ & $109 \mathrm{c}$ \\
\hline $\mathrm{Fe}(\mu \mathrm{g} / \mathrm{pot})$ & $1.522 \mathrm{c}$ & $2.776 \mathrm{a}$ & $2.098 \mathrm{~b}$ & $1.711 \mathrm{c}$ \\
\hline $\mathrm{Mn}(\mu \mathrm{g} / \mathrm{pot})$ & $3.320 \mathrm{a}$ & $1.816 \mathrm{~b}$ & $1.898 \mathrm{~b}$ & $1.890 \mathrm{~b}$ \\
\hline $\mathrm{Zn}(\mu \mathrm{g} / \mathrm{pot})$ & $605 \mathrm{~b}$ & $678 \mathrm{~b}$ & 927 a & 852 a \\
\hline
\end{tabular}

Different letters within rows indicate means that are significantly different by the Tukey test at $5 \%$. Absence of letters in rows indicates no significant difference by the $\mathrm{F}$ test. 
2. Highest $\mathrm{NO}_{3}, \mathrm{Ca}, \mathrm{Mg}, \mathrm{K}$, and $\mathrm{Na}$ concentrations in the soil leachate occurred at 60 days after limesludge application (leaching equivalent to 1 pore volume), but for $\mathrm{pH}$ and $\mathrm{SO}_{4}$, the maximum occurred on last sampling (leaching equivalent to 4 pore volumes).

3. Lime-sludgeapplication decreased exchangeable $\mathrm{Al}$ in the soil, and increased exchangeable $\mathrm{Na}$ and $\mathrm{SO}_{4}-\mathrm{S}$ concentrations in the soil.

4. At a high rate $\left(6 \mathrm{t} \mathrm{ha}^{-1}\right)$, lime-sludge increased eucalypt yield $65 \%$, markedly decreased the uptake of $\mathrm{Cu}$ and $\mathrm{Mn}$, and increased the uptake of $\mathrm{P}, \mathrm{K}, \mathrm{Ca}$, $\mathrm{B}$, and $\mathrm{Zn}$. There was no evidence of Na phytoxicity in eucalypts as a result of lime-sludge additions.

\section{LITERATURE CITED}

BELLAMY, K.L.; CHONG, C. \& CLINE, R.A. Paper sludge in agriculture and container nursery culture. J . Environ. Qual., 24:1074-1082, 1995.

BENEDETTI, V. Utilização de resíduos industriais da Ripasa S/A Celulose e Papel como insumos na produção florestal. In: SEMINÁRIO SOBRE USO DE RESÍ DUOS INDUSTRIAIS E URBANOS EM FLORESTAS, Botucatu, 1994. Anais. Botucatu, FEPAF, 1994. p.167-187.

BERGAMIN, F.N.; ZINI, C.A.; GONZAGA, J.V. \& BORTOLAS, E. Resíduo de fábrica de celulose e papel: lixo ou produto. In: SEMINÁRIO SOBRE USO DE RESÍDUOS INDUSTRIAIS E URBANOS EM FLORESTAS, Botucatu, 1994. Anais. Botucatu, FEPAF, 1994. p.97-120.

BOCKHEIM, J.G.; BENZEL, T.C.; LU, RUI-LIN \& THIEL, D.A. Groundwater and soil leachate inorganic nitrogen in a Wisconsin red pine plantation amended with paper industry sludge. J. Environ. Qual., 17:729-734, 1988.

DOLAR, S.G.; BOYLE, J .R. \& KEENEY, D.R. Papermill sludge disposal on soils: Effects on yield and mineral nutrition of oats (Avena sativa L.). J . Environ. Qual., 1:405-409, 1972.

EMPRESA BRASILEIRA DE PESQUISA AGROPECUÁRIA EMBRAPA. Manual de métodos de análise de solo. 2.ed. Rio deJ aneiro, Centro Nacional de Pesquisa de Solos, 1997. $212 p$.

GUERRINI, I.A. \& VILLAS-BÔAS, R.L. Uso de resíduos industriais em florestas. In: CONGRESSO LATINOAMERICANO DE CIÊNCIA DO SOLO, 13., Águas de Lindóia, 1996. Anais. Campinas, Sociedade Brasileira de Ciência do Solo, 1996. (CD-ROM)

HARKIN, J.M. Wise use of Wisconsin's papermill sludge. In: ROCK, C.A. \& ALEXANDER,J .A., eds. Long range disposal alternatives for pulp and paper sludges. Orono, University of Maine, 1982. p.65-78.

KIEHL, E.J . Fertilizantes orgânicos. Piracicaba, Agronômica Ceres, 1985. 492p.

LINDSAY, W.L. Chemical equilibria in soils. New York, J ohn Wiley $\&$ Sons, 1979. 449p.
MALAVOLTA, E.; VITTI, G.C. \& OLIVEIRA, S.A. Avaliação do estado nutricional das plantas: princípios e aplicações. Piracicaba, POTAFOS, 1989. 201p.

MENGEL, K.\& KIRKBY, E.A. Principles of plant nutrition. 3.ed. Bern, International Potash I nstitute, 1982. 655 p.

MUSE, J.K. \& MITCHELL, C.C. Paper mill boiler ash and lime by-products as soil liming materials. Agron. J ., 87:432-438, 1995.

NAYLOR, L.M. \& SCHMIDT, E.J . Agricultural use of wood ash as a fertilizer and liming material. Tappi J ., 69:114-119, 1986.

NOVAIS, R.F.; BARROS, N.F. \& NEVES, J.C.L. Nutrição mineral do eucalipto. In: BARROS, N.F. \& NOVAIS, R.F., eds. Relação solo-eucalipto. Viçosa, Folha de Viçosa, 1990. p.25-98.

PARFITT, R.L. Anion adsorption by soils and soil materials. Adv. Agron., 30:1-50, 1978.

RAIJ, B. van. Fertilidade do solo e adubação. Piracicaba, Agronômica Ceres/POTAFOS, 1991. 343p.

RAIJ, B. van; QUAGGIO, J.A.; CANTARELLA, H.; FERREIRA, M.E.; LOPES, A.S. \& BATAGLIA, O.C. Análise química do solo para fins de fertilidade. Campinas, Fundação Cargill, 1987. 170p.

STATISTICAL ANALYSIS SYSTEM INSTITUTE. SAS/STAT User's guide. v.1. 4.ed. Cary, SAS I nstitute, 1990. 1028p.

SIMSON, C.R.; KELLING, K.A. \& LIEGEL, E.A. Papermill lime sludge as an alternativeliming material. Agron. J ., 73:10031008, 1981.

SPOSITO, G.; LUND, L.J . \& CHANG, A.C. Trace metal chemistry in arid-zone field soil amended with sewage sludge. $I$. Fractionation of $\mathrm{Ni}, \mathrm{Cu}, \mathrm{Zn}, \mathrm{Cd}$, and $\mathrm{Pb}$ in soil phases. Soil Sci. Soc. Am.J ., 46:260-264, 1982.

STAPE, J.L. \& BALLONI, E.A. O uso de resíduos da indústria de celulose como insumos na produção florestal. IPEF, 40:33-37, 1988

TISDALE, S.L.; NELSON, W.L. \& BEATON, J.D. Soil fertility and fertilizers. New York, Macmillan, 1985. 754p.

UEHARA, G. \& GILLMAN, G.P. The mineralogy, chemistry, and physics of tropical soils with variable charge clays. Boulder, Westview Press, 1981. 170p.

UNITED STATES ENVIRONMENTAL PROTECTION AGENCY - USEPA. National interim primary drinking water regulations. Washington, USEPA, 1977. (EPA-570/ 976- 003)

UNITED STATES SALI NITY LABORATORY STAFF. Diagnosis and improvement of saline and alkaline soils. Washington, United States Department of Agriculture, 1969. 160p. (Agriculture Handbook, 60)

VITTI, G.C. Avaliação e interpretação do enxofre no solo e na planta. J aboticabal, FUNEP, 1989. 37p. (Bol etim técnico)

WHITE, R.E. Principles and practice of soil science. 3.ed. Oxford, Blackwell Science, 1997. 348p.

WILLIAMS, T.M.; HOLLIS, C.A. \& SMITH, B.R. Forest soil and water chemistry following bark boiler bottom ash application. J. Environ. Qual., 25:955-961, 1996. 
S.C. VETTORAZZO et al.

R. Bras. Ci. Solo, 25:755-763, 2001 